\title{
THE PATTERN OF ANTIBIOTIC PRESCRIPTION AND ANTIMICROBIAL RESISTANCE OF GUT FLORA Escherichia coli AT AISYIYAH HOSPITAL, BOJONEGORO
}

\author{
Ana Nurlaili Hidayah ${ }^{1}$, Didik Hasmono ${ }^{2}$, Muqoddar Thayyib ${ }^{3}$, Kuntaman $^{4}$ \\ ${ }^{1}$ Master Program of Clinical Pharmacy, ${ }^{2}$ Faculty of Pharmacy, Universitas Airlangga, ${ }^{3}$ Internist of Aisyiyah \\ Hospital, Bojonegoro, ${ }^{4}$ Faculty of Medicine, Universitas Airlangga, Surabaya, Indonesia
}

\section{ABSTRACT}

\begin{abstract}
Antimicrobial resistance $(A M R)$ is the failure of antibiotic to kill bacteria and becomes ineffective in therapeutic purpose. The AMR bacteria is a major health problem worldwide and Indonesia is not exception. AMR is increased by two factors, higher antibiotic use and low compliance in infection control and prevention. WHO has recommended 7 bacterial indicators as point of view in surveillance, one of these bacteria is Escherichia coli. This study aimed to analyze the correlation between antibiotic use and resistance pattern of gut flora Escherichia coli. The study was conducted at Aisyiyah Hospital, Bojonegoro from June to October 2017. Total 101 patients from internal medicine and surgery department in this hospital were included in this study. Bacterial gut flora were tested against 12 antibiotics by disk diffusion test at the Department of Clinical Microbiology, Universitas Airlangga.. The results showed that the highest quantity of antibiotic use in internal medicine service was cefepime $(40,50 \mathrm{DDD})$ and the highest resistance rate was ciprofloxacin, whereas in the surgical service it was ceftriaxone (132,75 $D D D)$ with the highest $E$. coli resistance to amoxicillin-clavulanic acid. The antibiotics use has significant correlation against E. coli resistance on cefotaxime $(p=0.046)$, ceftazidime $(p=0.046)$, ceftriaxone $(p=0.017)$, aztreonam $(p=0.024)$, and cefepime $(p=0.010)$.
\end{abstract}

Keywords: Antimicrobial resistance; Escherichia coli; antibiotics

\section{ABSTRAK}

Resistensi antimikroba adalah kegagalan antibiotik untuk membunuh bakteri dan menjadi tidak efektif dalam tujuan terapeutik. Bakteri AMR adalah masalah kesehatan utama di seluruh dunia dan Indonesia tidak terkecuali. AMR meningkat oleh dua faktor, penggunaan antibiotik yang lebih tinggi dan kepatuhan yang rendah dalam pengendalian dan pencegahan infeksi. WHO telah merekomendasikan 7 indikator bakteri sebagai sudut pandang dalam pengawasan, salah satu dari bakteri ini adalah Escherichia coli. Penelitian ini bertujuan untuk menganalisis hubungan antara penggunaan antibiotik dan pola resistensi usus flora Escherichia coli. Penelitian ini dilakukan di Rumah Sakit Aisyiyah, Bojonegoro dari Juni hingga Oktober 2017. Total 101 pasien dari bagian penyakit dalam dan operasi di rumah sakit ini dilibatkan dalam penelitian ini. Flora usus bakteri diuji terhadap 12 antibiotik dengan uji difusi cakram di Departemen Mikrobiologi Klinik, Universitas Airlangga. Hasil penelitian menunjukkan bahwa jumlah tertinggi penggunaan antibiotik dalam layanan pengobatan internal adalah cefepime (40,50 DDD) dan tingkat resistensi tertinggi adalah ciprofloxacin, sedangkan dalam layanan bedah itu adalah ceftriaxone (132,75 DDD) dengan resistensi E. coli tertinggi terhadap asam amoksisilin-klavulanat. Penggunaan antibiotik memiliki korelasi yang signifikan terhadap resistensi E. coli pada sefotaksim $(p=0,046)$, seftazidim $(p=0,046)$, seftriakson $(p=0,017)$, aztreonam $(p=0,024)$, dan sefepim $(p=0,010)$.

Kata kunci: Resistensi antimikroba; Escherichia coli; antibiotik

Correspondence: K. Kuntaman. Faculty of Medicine Universitas Airlangga, Surabaya, Indonesia.

E-mail: kuntaman@fk.unair.ac.id

pISSN:2355-8393 • eISSN: 2599-056x • doi: http://dx.doi.org/10.20473/fmi.v56i2.21227

- Fol Med Indones. 2020;56:99-107 • Received 20 Apr 2018 • Accepted 18 Oct 2018

- Open access under CC-BY-NC-SA license • Available at https://e-journal.unair.ac.id/FMI/

\section{INTRODUCTION}

The Europe of the health and economicburden states that deaths from resistant bacterial infections in Europe are estimated to be over 25,000 patients and according to a CDC report in the deaths in the United States is about 23,000 patients each year (WHO 2012, CDC
2013). The widespread of antibiotics use including their overuse and misuse induces the emergence of resistant bacteria through selective pressure and less compliance to infection control and prevention (Lestari et al 2008, Rice 2012, Taur \& Show 2013). 
E. coli was used as an indicator of antibiotic resistance surveillance as it is mostly found as bacterial gut flora in human beings (WHO 2014). These bacteria also indicate the appearance of resistance and potential widespread resistance to other gut flora will result in the emergence of a resistant population. It also can be easily and rapidly grown in vitro in the laboratory making it easy to be investigated (Todar 2008, Bartoloni et al 2006).

This study was conducted at Aisyiyah Hospital, Bojonegoro where no previous research has been done regarding the quantity data of antibiotics use and antibiogram. In relation to the rapid increase of Gram negative Enterobacteriaceae resistance, especially $E$. coli and the high trend of antibiotic usage at Asiyiyah Hospital Bojonegoro this research was focused to analyze the correlation between antibiotic prescription and resistance of gut flora Escherichia colias as the first step to optimize the antibiotics usage.

\section{MATERIALS AND METHODS}

Study site and period. The study design was observational cross sectional on the resistance pattern of gut flora E. coli. Inclusion criterion was hospitalized patients for more than or equal to three days. A number of 101 adult patients from internal medicine and surgery departement participated in this study. The sample used was a rectal swab specimen taken while the patient was discharged from the hospital which was collected from June to October 2017.

Antibiotic prescription. Antibiotic prescription data were extracted from the medical records from each patients. Defined daily dose (DDD) per patient for each drug or drug category prescribed every quarter was calculated following the World Health Organization (WHO) anatomical therapeutic chemical (ATC) classification system of 2017

Antibiotical resistance E. coli. Sample test started with Gram staining, bacterial inoculation on Mac Conkey media to be incubated at $35-37^{\circ} \mathrm{C}$ for 24 hours. E. coli bacteria colonies showed growth with round and smooth reddish color. Furthermore, the samples identified as $E$. coli were tested for antibiotics sensitivity qualitatively with disk diffusion test.

Statistical analysis. All data were analyzed by using the statistic software packages SPSS version 18.0. Each antibiotic prescription and resistance pattern of $E$. coli was analyzed descriptively. Chi square test was used to analyze correlation between $E$. coli resistance pattern and quantity of antibiotic usage.The criterion for statistical significance was a p-value $<0.05$.

\section{RESULTS}

Characteristic data of research subjects are found in Table 1. Eighty samples were identified $E$. coli consisting of $41(51.3 \%)$ patients in internal medicine departement and $39(48.7 \%)$ of surgery department. Male patients were as many as $42(52.5 \%)$ and female patients were as many as $38(47.5 \%)$, with age mostly between $18-65$ years, in as 56 patients $(70.0 \%)$, with an average age of 54.47 years (range 17-82 years).

Bacterial identification data were found in Table 2. Based on identification through rectal swab specimens it was found that 80 samples were identified as $E$. coli, in which $77(76.2 \%)$ was ESBL negative $E$. coli comprising $40(51.9 \%)$ from internal medicine samples and $37(48.1 \%)$ from sugery sample, while 3 samples were identified as ESBL positive $E$. coli that included 1 $(33.3 \%)$ internal medicine samples and $2(66.7 \%)$ surgery samples. Of the 21 samples identified as not $E$. coli, 19 samples were identified Gram negative non $E$. coli in which 17 samples were identified as Klebsiella sp, 1 sample of Pseudomonas sp. and 1 sample of Salmonella sp. Of the remaining 2 samples, there were no bacterial growth and both were surgical samples.

E. coli resistance data based on the type of health service is presented in Table 3. Eighty samples were identified as $E$. coli which then tested with antibiotic sensitivity of Kirby Bauer method with 12 types of antibiotic testing of amoxicillin-clavulanic acid (AMC), cefotaxime (CTX), ceftazidime (CAZ), ceftriaxone (CRO), aztreonam (ATM), cefepime (FEP), ciprofloxacin (CIP), amikacin (AK), meropenem (MEM), pipperacillin-tazobactam (TZP), fosfomycin (FOS), and cefoperazone-sulbactam (SCF). Twenty one samples could not be tested for antibiotic sensitivity because they were identified as not $E$. coli.

Resistance profiles of internal medicine samples showed that $E$. coli was most resistant to ciprofloxacin, and that from surgery sample to amoxicillin-clavulanic acid. Chi Square analysis showed that significant differences of $E$. coli resistance between samples from internal medicine and surgery to meropenem $(\mathrm{p}=0.001)$ and cephoperazon-sulbactam $(\mathrm{p}=0.035)$. 
Table 1. Characteristics of research subjects

\begin{tabular}{|c|c|c|c|c|c|c|}
\hline No & $\begin{array}{l}\text { Characteristics of } \\
\text { research subject }\end{array}$ & Description & $\begin{array}{l}\text { Identified } E \text {. coli } \\
\quad(\mathrm{N}=80)\end{array}$ & $\begin{array}{c}\text { Identified } \\
\text { Non } E \text {. coli } \\
(\mathrm{N}=21)\end{array}$ & $\begin{array}{l}\text { Total Samples } \\
\quad(\mathrm{N}=101)\end{array}$ & $\begin{array}{c}\mathrm{P}- \\
\text { value }\end{array}$ \\
\hline \multirow[t]{2}{*}{1} & Type of Service & Internal medicine & $41(51.3 \%)$ & $9(42.9 \%)$ & $50(49.5 \%)$ & 0.494 \\
\hline & & surgery & $39(48.7 \%)$ & $12(57.1 \%)$ & $51(50.5 \%)$ & \\
\hline \multirow[t]{3}{*}{2} & Age & $18-65$ years & $56(70 \%)$ & $16(76.2 \%)$ & $71(70.3 \%)$ & 0.576 \\
\hline & & $66-79$ years & $18(22.5 \%)$ & $5(23.8 \%)$ & $23(22.8 \%)$ & \\
\hline & & $80-99$ years & $6(7.5 \%)$ & $0(0 \%)$ & $6(5.9 \%)$ & \\
\hline \multirow[t]{2}{*}{3} & Sex & Female & $38(47.5 \%)$ & $9(42.9 \%)$ & $47(46.5 \%)$ & 0.074 \\
\hline & & Male & $42(52.5 \%)$ & $12(57.1 \%)$ & $54(53.5 \%)$ & \\
\hline \multirow[t]{3}{*}{4} & Underwriting & BPJS & $44(55 \%)$ & $8(38.1 \%)$ & $52(51.5 \%)$ & 0.195 \\
\hline & Status & Other insurance & $3(3.8 \%)$ & $0(0 \%)$ & $3(3 \%)$ & \\
\hline & & Non Insurance & $33(41.2 \%)$ & $13(61.9 \%)$ & $46(45.5 \%)$ & \\
\hline
\end{tabular}

Table 2. Distribution of bacteria identification

\begin{tabular}{|c|c|c|c|c|c|}
\hline \multirow[b]{2}{*}{ No } & \multirow[b]{2}{*}{ Bacterial profile } & \multicolumn{3}{|c|}{ Type of Service } & \multirow[b]{2}{*}{ P-value } \\
\hline & & Internal Medicine & Surgery & Total & \\
\hline 1 & No bacterial growth & $0(0 \%)$ & $2(3.9 \%)$ & $2(2 \%)$ & 0.157 \\
\hline 2 & $\begin{array}{l}\text { Escherichia coli } \\
\text { - E. coli }(\text { Non ESBL) } \\
\text { - coli }(\text { ESBL+) }\end{array}$ & $\begin{array}{c}40(80 \%) \\
1(2 \%)\end{array}$ & $\begin{array}{c}37(72.5 \%) \\
2(3.9 \%)\end{array}$ & $\begin{array}{c}77(76.2 \%) \\
3(3 \%)\end{array}$ & 0.494 \\
\hline 3 & $\begin{array}{l}\text { Gram negative non } \\
\text { Escherichia coli }\end{array}$ & $9(18 \%)$ & $10(19.7 \%)$ & $19(18.8 \%)$ & 0.836 \\
\hline & Total & $50(100 \%)$ & $51(100 \%)$ & $101(100 \%)$ & \\
\hline
\end{tabular}

Table 3. Distribution of E. coli resistance data and chi square output between variables type of service with $E$. coli resistance pattern

\begin{tabular}{llccc}
\hline \multirow{2}{*}{ No } & \multirow{2}{*}{ Tested AB } & \multicolumn{2}{c}{ Resistance } & \multirow{2}{*}{ P-value } \\
\cline { 3 - 4 } & & Internal Medicine & Surgery & 0.468 \\
2 & AMC & $18(45 \%)$ & $22(55 \%)$ & 0.279 \\
3 & CAX & $15(42.9 \%)$ & $20(57.1 \%)$ & 0.352 \\
4 & CRO & $14(48.3 \%)$ & $15(51.7 \%)$ & 0.281 \\
5 & ATM & $16(48.5 \%)$ & $17(51.5 \%)$ & 0.631 \\
6 & FEP & $14(45.2 \%)$ & $17(54.8 \%)$ & 0.427 \\
7 & CIP & $13(43.3 \%)$ & $17(56.7 \%)$ & 0.559 \\
8 & AK & $21(52.5 \%)$ & $19(47.5 \%)$ & 0.193 \\
9 & MEM & $3(100 \%)$ & $0(0 \%)$ & 0.001 \\
10 & TZP & $4(66.7 \%)$ & $2(33.3 \%)$ & 0.068 \\
11 & FOS & $3(60 \%)$ & $2(40 \%)$ & 0.050 \\
12 & SCF & $5(100 \%)$ & $0(0 \%)$ & 0.035 \\
\hline
\end{tabular}

Note: $\mathrm{AB}=$ Antibiotics; $\mathrm{AMC}=$ Amoxicilline-clavulanic acid; $\mathrm{CTX}=$ Cefotaxime; $\mathrm{CAZ}=$ Ceftazidime; $\mathrm{CRO}=$ Ceftriaxone; ATM=Aztreonam; $\quad$ FEP=Cefepime; $\quad \mathrm{CIP}=$ Ciprofloxacin; $\mathrm{AK}=$ Amikacin; $\quad \mathrm{MEM=Meropenem;} \mathrm{TZP}=\mathrm{Piperacillin-}$ Tazobactam; FOS=Fosfomycin; $\mathrm{SCF}=$ Cefoperazon-sulbactam

Antibiotic usage data based on the service is shown in Table 4. From 50 internal medicine patients involved in the study, $36(72 \%)$ patients received antibiotics and 14 $(28 \%)$ of patients did not receive antibiotics, while from
51 surgical patients, 49 (96\%) received antibiotics and only $2(4 \%)$ did not received. From the results of chi square analysis significant correlation was found between the type of health service and antibiotics usage. 
Table. 4 Profile of antibiotic use in each type of health service

\begin{tabular}{lcccc}
\hline \multirow{2}{*}{ Type of Service } & \multicolumn{2}{c}{ Antibiotics use } & \multirow{2}{*}{ Total } & \multirow{2}{*}{ P-value } \\
\cline { 2 - 3 } & Yes & No & & \\
\hline Internal Medicine $(\mathrm{N}=50)$ & $36(72 \%)$ & $14(28 \%)$ & 50 & \\
Surgery $(\mathrm{N}=51)$ & $49(96 \%)$ & $2(4 \%)$ & 51 & 0.001 \\
Total & 85 & 16 & 101 & \\
\hline
\end{tabular}

Table 5. Distribution of antibiotic use in total DDD

\begin{tabular}{|c|c|c|c|c|c|c|c|}
\hline \multirow[t]{2}{*}{ No } & \multirow[t]{2}{*}{ Antibiotics } & \multicolumn{2}{|c|}{ Internal Medicine } & \multicolumn{2}{|c|}{ Surgery } & \multicolumn{2}{|c|}{ Total } \\
\hline & & Frequency & DDD & Frequency & DDD & Frequency & DDD \\
\hline 1 & $\mathrm{CRO}$ & $15(24.59 \%)$ & 37.00 & $31(44.29 \%)$ & 132.75 & $46(35.12 \%)$ & 169.75 \\
\hline 2 & FEP & $10(16.39 \%)$ & 40.50 & $7(10.00 \%)$ & 45.50 & 17 L12.98\%) & 86.00 \\
\hline 3 & $\mathrm{ZOX}$ & $2(3.27 \%)$ & 5.00 & $9(12.86 \%)$ & 11.75 & $11(8.40 \%)$ & 16.75 \\
\hline 4 & FUR & $8(13.11 \%)$ & 13.35 & $2(2.86 \%)$ & 3.34 & $10(7.63 \%)$ & 16.69 \\
\hline 5 & MTZ & $1(1.64 \%)$ & 2.00 & $10(14.27 \%)$ & 43.34 & $11(8.40 \%)$ & 45.34 \\
\hline 6 & MEM & $4(6.56 \%)$ & 18.00 & $2(2.86 \%)$ & 11.50 & $6(4.58 \%)$ & 29.50 \\
\hline 7 & CTX & $0(0.00 \%)$ & 0 & $2(2.86 \%)$ & 4.75 & $2(1.53 \%)$ & 4.75 \\
\hline 8 & FOS & $1(1.64 \%)$ & 2.00 & $0(0.00 \%)$ & 0 & $1(0.76 \%)$ & 2.00 \\
\hline 9 & CIP & $6(9.84 \%)$ & 17.20 & $1(1.44 \%)$ & 4.50 & $75.34 \%)$ & 21.70 \\
\hline 10 & AMX & $2(3.28 \%)$ & 9.00 & $0(0.00 \%)$ & 0 & $2(1.53 \%)$ & 9.00 \\
\hline 11 & EMB & $2(3.28 \%)$ & 5.83 & $0(0.00 \%)$ & 0 & $2(1.53 \%)$ & 5.83 \\
\hline 12 & $\mathrm{AK}$ & $1(1.64 \%)$ & 3.00 & $1(1.44 \%)$ & 3.00 & $2(1.53 \%)$ & 6.00 \\
\hline 13 & LEV & $4(6.56 \%)$ & 20.00 & $3(4.26 \%)$ & 8.00 & $7(5.34 \%)$ & 28.00 \\
\hline 14 & AMC & $1(1.64 \%)$ & 4.50 & $0(0.00 \%)$ & 0 & $1(0.76 \%)$ & 4.50 \\
\hline 15 & PA & $1(1.64 \%)$ & 1.00 & $0(0.00 \%)$ & 0 & $1(0.76 \%)$ & 1.00 \\
\hline 16 & GEN & $0(0.00 \%)$ & 0 & $2(2.86 \%)$ & 9.55 & $2(1.53 \%)$ & 9.55 \\
\hline 17 & RIF & $1(1.64 \%)$ & 1.50 & $0(0.00 \%)$ & 0 & $1(0.76 \%)$ & 1.50 \\
\hline 18 & INH & $1(1.64 \%)$ & 1.00 & $0(0.00 \%)$ & 0 & $1(0.76 \%)$ & 1.00 \\
\hline \multirow[t]{2}{*}{19} & DOX & $1(1.64 \%)$ & 1.00 & $0(0.00 \%)$ & 0 & $1(0.76 \%)$ & 1.00 \\
\hline & Total & $61(100 \%)$ & 181.88 & $70(100 \%)$ & 277.98 & $131(100 \%)$ & 459.86 \\
\hline & $\begin{array}{l}\mathrm{MC}=\text { Amoxi } \\
\mathrm{K}=\text { Amikaci } \\
\text { ITZ=Metron }\end{array}$ & $\begin{array}{l}\text { clavulanic } \\
\text { EM=Merope }\end{array}$ & $\mathrm{EMB}=\mathrm{E}$ & $\begin{array}{l}\text { ime; CRO } \\
\text { utol; FOS= } \\
=\text { Levofloxa }\end{array}$ & $\mathrm{PA}=\mathrm{F}$ & $\begin{array}{l}\mathrm{P}=\text { Cefepime; } \\
\mathrm{X}=\text { Ceftizoxim, } \\
\text { idic Acid; }\end{array}$ & $\begin{array}{l}\text { Ciprofloxacin; } \\
\text { 2=Cefuroxime, } \\
\text { V=Gentamicin; }\end{array}$ \\
\hline
\end{tabular}

Antibiotic use data in total DDD is shown in Table 5. From the DDD calculation from 19 antibiotics used in 101 samples, we found that antibiotics with the highest use in internal medicine service was cefepime, which was in 10 samples with a total 40.50 DDD. Antibiotics with the highest use in surgery service was ceftriaxone, in 31 samples with a total 132.75 DDD. Results of Chisquare test showing correlation between sex and age with resistance $E$. coli are presented in Table 6 . Sex correlated to $E$. coli resistance against piperacilintazobactam, while age correlated to E coli resistance to ciprofloxacin.

Results of partial effect analysis between antibiotic use (in DDD) and the type of service in the resistance pattern is presented in Table 9. The type of service relates to $E$. coli resistance to piperacillin-tazobactam, fosfomycin and cefoperazon-sulbactam, while total antibiotics usage in DDD that are associated with $E$. coli resistance to cefepime, amikacin, meropenem, fosfomycin, and cefoperazone-sulbactam.

\section{DISCUSSION}

This was a prospective analytic observational study aimed to analyze correlation between antibiotic use and gut flora $E$. coli resistance. Many studies involved pathogenic bacteria from clinical isolates and in some cases are limited to facultative bacteria. 
Table 6. Correlation between sex and age with E. coli resistance

\begin{tabular}{|c|c|c|c|}
\hline \multirow{2}{*}{ No } & \multirow{2}{*}{ Antibiotics } & \multicolumn{2}{|c|}{$\mathrm{P}$} \\
\hline & & Sex & Age \\
\hline 1 & AMC & 0.163 & 0.328 \\
\hline 2 & CTX & 0.490 & 0.692 \\
\hline 3 & CAZ & 0.137 & 0.416 \\
\hline 4 & CRO & 0.244 & 0.485 \\
\hline 5 & ATM & 0.171 & 0.586 \\
\hline 6 & FEP & 0.362 & 0.387 \\
\hline 7 & CIP & 0.397 & 0.047 \\
\hline 8 & $\mathrm{AK}$ & 0.710 & 0.075 \\
\hline 9 & MEM & 0.218 & 0.522 \\
\hline 10 & $\mathrm{TZP}$ & 0.042 & 0.432 \\
\hline 11 & FOS & 0.544 & 0.945 \\
\hline 12 & SCF & 0.282 & 0.940 \\
\hline
\end{tabular}

Table 7. Correlation of antibiotic use (in \%) to E. coli resistance

\begin{tabular}{|c|c|c|c|}
\hline No & Antibiotics Test & Sig. & $\mathrm{R}$ \\
\hline 1 & AMC & 0.351 & 0.106 \\
\hline 2 & CTX & 0.014 & 0.273 \\
\hline 3 & CAZ & 0.046 & 0.224 \\
\hline 4 & $\mathrm{CRO}$ & 0.017 & 0.266 \\
\hline 5 & ATM & 0.024 & 0.252 \\
\hline 6 & FEP & 0.010 & 0.285 \\
\hline 7 & CIP & 0.269 & 0.125 \\
\hline 8 & $\mathrm{AK}$ & 0.322 & 0.112 \\
\hline 9 & MEM & 0.830 & 0.024 \\
\hline 10 & $\mathrm{TZP}$ & 0.937 & 0.009 \\
\hline 11 & FOS & 0.965 & 0.005 \\
\hline 12 & SCF & 0.643 & 0.053 \\
\hline Note: & $\begin{array}{ll}\mathrm{AB}=\text { Antibiotics; } & \mathrm{AMC}=\text { Amoxicilline-c } \\
\mathrm{CAZ}=\text { Ceftazidime; } & \mathrm{CRO}=\text { Ceftriaxone; } \\
\mathrm{CIP}=\text { Ciprofloxacin; } & \mathrm{AK}=\text { Amikacin; }\end{array}$ & $\begin{array}{l}\text { lavulanic acid; } \\
\text { ATM=Aztreonam; } \\
\text { MEM=Meropenem; } \\
\text { nerazon-sulbactam }\end{array}$ & $\begin{array}{r}\text { CTX=Cefotaxime; } \\
\text { FEP=Cefepime; } \\
\text { TZP=Piperacillin }\end{array}$ \\
\hline
\end{tabular}

Table 8 Correlation between total DDD on E. coli resistance

\begin{tabular}{|c|c|c|c|}
\hline No & Tested AB & Sig. & $\mathrm{R}$ \\
\hline 1 & AMC & 0.059 & 0.212 \\
\hline 2 & CTX & 0.003 & 0.327 \\
\hline 3 & CAZ & 0.010 & 0.285 \\
\hline 4 & $\mathrm{CRO}$ & 0.004 & 0.322 \\
\hline 5 & ATM & 0.007 & 0.297 \\
\hline 6 & FEP & 0.000 & 0.389 \\
\hline 7 & CIP & 0.014 & 0.274 \\
\hline 8 & $\mathrm{AK}$ & 0.314 & 0.114 \\
\hline 9 & MEM & 0.413 & 0.093 \\
\hline 10 & TZP & 0.462 & 0.083 \\
\hline 11 & FOS & 0.528 & 0.072 \\
\hline 12 & SCF & 0.248 & 0.131 \\
\hline Note: & $\begin{array}{l}\mathrm{AB}=\text { Antibiotics; } \\
\mathrm{CAZ}=\text { Ceftazidime; } \\
\mathrm{CIP}=\text { Ciprofloxacin; } \\
\text { Tazobactam; FOS=F } \\
\text { Dose }\end{array}$ & $\begin{array}{l}\text { AMC=Amoxiline-cla } \\
\text { CRO=Ceftriaxone; } \\
\text { AK=Amikacin; } \\
\text { osfomycn; SCF=Cefor }\end{array}$ & $\begin{array}{lr}\text { vulanic acid; } & \text { CTX=Cefotaxime; } \\
\text { ATM=Aztreonam; } & \text { FEP=Cefepime; } \\
\text { MEM=Meropenem; } & \text { TZP=Piperacillin- } \\
\text { perazon-sulbaktam, DDD=Defined Daily }\end{array}$ \\
\hline
\end{tabular}


Table 9. Partial effect of antibiotics usage (in DDD) on the type service on E. coli resistance

\begin{tabular}{|c|c|c|c|c|c|}
\hline \multirow{2}{*}{ No } & \multirow{2}{*}{ Tested AB } & \multicolumn{2}{|c|}{ OR (Odds Ratio) } & \multicolumn{2}{|c|}{ B (regression coefficient) } \\
\hline & & Type of service & Total DDD & Type of service & Total DDD \\
\hline 1 & AMC & 0.641 & 0.843 & -0.445 & -0.171 \\
\hline 2 & CTX & 0.287 & 0.575 & -1.250 & -0.554 \\
\hline 3 & CAZ & 0.479 & 0.775 & -0.737 & -0.255 \\
\hline 4 & $\mathrm{CRO}$ & 0.461 & 0.831 & -0.774 & -0.186 \\
\hline 5 & ATM & 0.485 & 0.870 & -0.724 & -0.139 \\
\hline 6 & FEP & 0.562 & 1.071 & -0.576 & 0.068 \\
\hline 7 & CIP & 0.351 & 0.968 & -1.048 & -0.033 \\
\hline 8 & $\mathrm{AK}$ & 0.936 & 1.462 & -0.067 & 0.380 \\
\hline 9 & MEM & 0.167 & 1.096 & -1.792 & 0.091 \\
\hline 10 & $\mathrm{TZP}$ & 2.372 & 0.747 & 0.864 & -0.292 \\
\hline 11 & FOS & 1.406 & 2.961 & 0.340 & 1.085 \\
\hline 12 & SCF & 3.373 & 1.056 & 1.216 & 0.055 \\
\hline
\end{tabular}

Antibiotics use does not only affect the pathogenic bacteria, but also the human normal microflora including E. coli. It is important to carry out further investigation because these bacteria can colonize and potentially transfer resistance to human pathogenic bacteria (Barbosa \& Levy 2010). From June to October 2017, there were 101 patients who met the inclusion criteria. From Table 1 on patient's characteristics, there were no significant differences between internal medicine and surgical services $(p=0.494)$, sex $(p=0.074)$, age $(p=0.576)$ and insurance status $(p=0.195)$. This reflects that the randomization technique was quite in this study.

From 101 rectal swab specimens, 80 samples were identified as $E$. coli in which $E$. coli producing ESBL was in 3 samples and the remaining were on ESBL $E$. coli. The analysis was performed only in patients with $E$. coli isolates, aiming to reduce the bias of analysis due to differences in bacterial species.

Analysis of correlation between age and resitance pattern of E.coli by chi square test revealed that age had a significant correlation with $E$. coli resistance to ciprofloxacin (Table 6). This is possible because of age restriction related to of fluoroquinolone prescription including ciprofloxacin, thus minimizing the exposure of ciprofloxacin in certain age groups. A study by Arce et al (2011) found that age, sex and source of infection were the determinants of $E$. coli resistance modulation. Both males and females show enhanced resistance as age increases. Resistance in females tends to be constant or elevates slightly during delivery and increases rapidly in the premenopausal period. Males show increased resistance at pubertal age. Although the effect of age on increased resistance can only be explained in terms of the higher exposure to antibiotics (Arce et al 2011).
Livemore et al (2003) suggested that the prevalence of ciprofloxacin-resistant $E$. coli was closely related to male sex with bacteremia, slightly correlated with age, and the peak resistance was in 15-44 age group.

The result of descriptive analysis on $E$. coli resistance pattern on 12 tested antibiotics revealed that the highest resistance in internal medicine department was to ciprofloxacin while that in surgery department was to amoxicillin-clavulanic acid (Table 3). Previous study (Arce et al 2011) also showed similar results. Amoxicillin-clavulanic acid and ciprofloxacin-resistant E coli were the first of $100,000 \mathrm{E}$. coli isolates tested. This is related to the overuse of both antibiotics in the community, which may be due to the presence of parenteral forms, amoxicillin-clavulanic acid and ciprofloxacin also available orally, so that their use is not limited only to hospital setting, but also to communities (Pedrera V et al 2004, Arce et al 2011). In addition, broad-spectrum antibiotic use is widely reported as a major cause of increasing resistance (Michael et al 2014) and it is well known that both amoxicillin-clavulanic acid and ciprofloxacin have broad spectrum activity.

From the sensitivity profile of 41 samples from internal medicine departement, $E$. coli was mostly sensitive to piperacillin-tazobactam, amikacin, and cefoperazonsulbactam, while from 39 samples from surgery department $E$. coli was most sensitive to fosfomycin. A study by Arce et al (2011) also showed similar results. This is possible because amikacin and fosfomycin are potent antibiotics with narrow spectrum activity, used only in hospital setting rather than first-line therapy, so that selective pressure effect is small due to limited use (Arce et al 2011). High sensitivity of piperacillin- 
tazobactam and cefoperazon-sulbactam was possible because of their limited use, even not used in patients involved in this study (Table 5).

In this study, the ATC antibiotic code used in all samples of 9 groups with 19 different class of antibiotics. Based on the calculation of total DDD from 101 patients found that the highest of antibiotics use in internal medicine services was cefepime of 40.50 DDD, whereas in surgical service the highest was ceftriaxone of 132.5 DDD (Table 5). The widely prescription of ceftriaxone may be due to a profile of tissue penetration, a broad spectrum activity and low toxicity, so it can be used as a therapy for treating life-threatening infections, especially if the causative organism has not been isolated previously (Pottinger et al 2014). Cefepime is a fourth generation cephalosprorin with clinical benefits similar to that of the third generation but with better activity against P. aeruginosa (Pottinger et al 2014). In addition to the consideration of pharmacological activity, the high use of third and fourth generation cephalosprorins is also possible in health insurance status. Patients with BPJS status tend to be higher in number than patients with private or non-insurance status (Table 1). Ceftriaxone and cefepime are listed in a national formulary with no specific restriction on their use.

Descriptive analysis of antibiotic usage in both types of health services showed that the use of antibiotics in surgical services was higher than in internal medicine, ie, $96 \%$ vs $72 \%$ (Table 4). This is because the administration of antibiotics in surgical services is not only intended as causative therapy of infectious diseases but also as prophylaxis.

Several previous studies have been conducted to analyze the effect of quantity of antibiotic prescription on $E$. coli resistance. In the Netherlands, elevated $E$. coli-resistant norfloxacin correlated with an increase in fluoroqunolone prescribing in urinary tract infections (Goettsch et al 2000). A 2006-2008 surveillance study involving 4 general hospitals in Singapore showed similar results, cross-correlation analysis demonstrated possible associations between prescription of fluoroquinolones and ciprofloxacin-resistant $E$. coli $(\mathrm{R} 2=0.46)$, fluoroquinolones and ceftriaxone-resistant E. coli $(\mathrm{R} 2=0.47)$, and carbapenems and imipenemresistant Acinetobacter spp. $(\mathrm{R} 2=0.48)$ (Li-Yang et al 2010)

Regression test was used to analyze the effect of antibiotic usage quantitatively against $E$. coli resistance. The results was found that the quantity of antibiotic use in DDD had a positive effect on E. coli resistance on cefotaxime $\quad(p=0.003)$ ceftazidime $\quad(p=0.010)$, ceftriaxone $(p=0.004)$, aztreonam $(p=0.007)$, cefepime $(\mathrm{p}=0.000)$, and ciprofloxacin $(\mathrm{p}=0.014)$ (Table 8). When viewed from the antibiotic use profile (Table 5), where the highest use of ceftriaxone was in the surgery department and cefepime in internal medicine departement, this reinforces the results of this regression analysis. It has been recognized that cefotaxime, ceftazidim, aztreonam and cefoperazone - sulbactam have the same core structure as ceftriaxone and cefepimeie the $\beta$-lactam ring that allows cross resistance against the four antibiotics of the tested. DDD antibiotics also affect the resistance of $E$. coli to ciprofloxacin. This is possible because of transferable resistance, clonal spread and mutation due to selection pressure by antibiotics usage (Kuntaman et al 2005).

Direct correlation between the antibiotic usage quantitatively and increased resistance can not be easily determined, although widely use of antibiotics is the major cause of resistance. On the other hand, there are many factors that influence resistance, such as crossselection, spread, antibiotic residues, resistant gene transfer, infection control, patient transfer in a health institution, community mobility and socioeconomic factors (Alekshun \& Levy 2000, Barbosa \& Levy 2010). In short, resistance phenomena can be focused on two factors, ie the use of antibiotics as agents that have selective activity and the ability of bacteria to propagate their resistant genes through various mechanisms either through plasmids, extracromosomal elements or bacteriophage (Levy 2002). However, this study did not determine the effect of other factors on $E$. coli resistance.

Quality analysis becomes important to determine prudence in the use of antibiotics. Prudent use of antibiotics is their use appropriate to the cause of infection with optimal dosing regimens, optimal duration of administration, minimal side effects and minimal impact of the emergence of resistant bacteria. Prudent use of antibiotics require policy restrictions in its application (Kemenkes RI 2015).

The results of quantity and quality analysis on effect of antibiotic use againts $E$. coli resistance encouraged the establishment and implementation of guidelines for antibiotics use at Aisyiyah Hospital Bojonegoro. The aim of prudent use antibiotic is to optimize therapeutic effect of the antimicrobial agent while minimizing the development of antimicrobial resistance. Its implementation required the role and cooperation of clinicians, clinical microbiologists, pharmacists and nurses. 


\section{CONCLUSION}

Antibiotics use has been shown to have significant effect on $E$. coli resistance to cefotaxime, ceftazidime, ceftriaxone, aztreonam, and cefepime. The results of quantity and quality analysis on the effect of antibiotic use on $E$. coli resistance encourage the establishment and implementation of guidelines for antibiotics use at Aisyiyah Hospital Bojonegoro.

\section{ACKNOWLEDGMENT}

The authors are grateful to the Director, Ethics Team, Health Service Division of Aisyiyah Hospital Bojonegoro, and the patients who had involved in this study. The author also grateful to the Dean of Faculty of Pharmacy Universitas Airlangga University, Head of Pharmacy Clinic Department, and the lecturers of the Clinical Pharmacy Master Program, Universitas Airlangga, Surabaya.

\section{REFERENCES}

Alekshun MN, Levy SB (2000). Bacterial drug resistance: Response to survival threats, In: Storz, G., Hengge-Aronis R, eds. Bacterial Stress Responses. Washington, ASM Press, p 323-366

Arce JM, Selva M, Perpinan H, Gubernado M, Armero CC, Quilez AL, Gonzales F, Vanachlocha H (2011). Antimicrobial resistance according to age, gender, culture site and patient location in more than 100.000 Escherichia coli. Journal of Antimicrobial Agents Chemotherapy. DOI: 10.1128/AAC.00765-10

Bartoloni A, Benedetti M, Pallecchi L, et al (2006). Evaluation of a rapid screening method for detection of antimicrobial Resistance in the commensal microbiota of the gut. Trans R Soc Trop Med Hyg, 119-125

Barbosa TM, Levy SB (2000). The impact of antibiotics use on resistance development and persistemce. Drug Resist Update 3, 301-311

Carol KC, Butel JS, Morse SA, Mietzner T (2016). Bacteriology in Jawetz, Melnick \& Adelberg's medical microbiology. 27th Ed. New York, McGraw Hill Education, p 159-397

Centers for Disease Control and Prevention (2013). Antibiotic resistance threats in the United States. Available at http://www.cdc.gov/drug resistance/threat-report-2013/pdf/ar-threats-2013508.pdf

Goettsch W, van Pelt W, Nagelkerke N, et al (2000). Increasing resistance to fluoroquinolones in $E$. coli from urinary tract infection in Netherlands. J. Antimicrob Chemother, 223-228
Kemenkes RI (2015). PMK Nomor 8 Tahun 2015 Tentang Program Pengendalian Resistensi Antimikroba di Rumah Sakit. Jakarta, Kemenkes

Kuntaman K, Lestari E, Severin J, Kershof I, Mertaningsih N, Purwanta M, et al (2005). Fluorokuinolon-resistant Escherichia coli, Indonesia. Emerging Infectious Disease 11, 1363-1369

Lestari ES, Severis JA, Filius PMG, et al (2007). Antimicrobial resisteance among commensal isolates of Escherichia coli and Staphylococcus aureus in the Indonesian population inside and outside hospitals. Eur J Clin Microbiol Infect Di 27, 45-51

Livermore DMR, Hope G, Brick M, Lilie R, Reynolds, BSAC (2008). Working parties on resistance surveillance. Non-susceptibility trends among Pseudomonas aeuginosa and other non-fermentative gram-negative bacteremiaes in UK and Ireland, 200106. J. Antimicrob. Chemother 62, ii55-63

Levy SB (2002). Factors impacting on the problem of antibiotic resistance. J. Antimicrob. Chemother 49, 25-30

Li-Yang H, Thean-Yen T, Vincent HT, Andrea K, Dale AF, Tse-Hsien K, The Network for Antimicrobial Surveillance (Singapore) (2010). Surveillance and correlation of antibiotic prescription and resistance of Gram negative bacteria in Singaporean hospital. Antimicrobial Agent and Chemotherapy 54, 11731178

Michael CA, Dominey-Howes D, Labbate M (2014). The antimicrobial resistance crisis: Causes, consequences, and management. Infectious Disease 2, $1-8$

Pedrera V, Schwarz H, de la Torre MP, Gil-Guillén V, Orozco D, Canelles JM (2004). Analysis of antibiotic use in the community of Valencia (2000-2002). Enferm Infecc Microbiol Clin 22, 385-389

Pottinger P, Reller LB, Ryan KJ (2014). Pathogenic bacteria, in K. J. Ryan, \& C. G. Ray, Sherris Medical Microbiology. 6th Ed. New York, McGraw Hill Education, p 253-290

Rice LB (2012). Gastrointestinal bacteria will have its way. The Journal of Infectious Diseases 206, 13341335

Rice LB (2016). Mechanism of resistance to antimicrobial agent, in LaPlante, K. L., Cunha, C. B., Morrill, H. J., Rice, L. B, Antimicrobial Stewardship Principle and Practice. 1st Ed.Oxfordshire, CABI, p 39-52

Taur Y, Pamer EG (2013). The intestinal microbiota and susceptibility to infection in immunocompromised patients. Current Opinion in Infectious Diseases 26, 332-337

Todar K (2004). The normal bacterial flora of humans, in Todar's Online Textbook of Bacteriology. Available at www.textbookofbacteriology.net. Accessed April 6, 2017 
WHO (2012). The evolving threat of antimicrobial resistance: Options for Actions. WHO Patient Safety Programme. Geneva, GPS Publishing, p 1-119
WHO (2014). Antimicrobial resistance. Global Report on Surveillance. Geneva, WHO Publishing, p 1-256 